\title{
SAMORZĄD TERYTORIALNY JAKO PODMIOT ADMINISTRACJI ŚWIADCZĄCEJ
}

Pozycja samorządu terytorialnego jako podmiotu administracji świadczącej przez lata nie podlegała w doktrynie zakwestionowaniu. To samorzą postrzegano jako podmiot zaspokajania podstawowych potrzeb z zakresu pomocy społecznej, kształcenia, oświaty przedszkolnej czy podstawowej szkoły publicznej, ale również - w nawiązaniu do klasycznej konstrukcji Ernsta Forsthoffa ${ }^{1}$ - dostarczania wody, ciepła i energii elektrycznej. Postępująca prywatyzacja usług publicznych - zaakceptowana przez nasze państwo w nadspodziewanie szerokim zakresie - podważała tę rolę samorządu stopniowo, ale systematycznie. Osiagnięty obecnie stan, w którym po raz pierwszy mamy gminy, w których nie ma ani jednej szkoły publicznej, a także powiaty bez jednego publicznego szpitala, nie mówiąc już o prywatyzacji przedsiębiorstw energetycznych, każe postawić pytanie o konsekwencje tego trendu dla samych podstaw pozycji prawnej samorządu terytorialnego. Charakterystyczne jest przy tym stopniowe zastępowanie w debacie publicznej pojęć „wykonywania zadań publicznych” i „zaspokajania potrzeb” mieszkańców - kategorią świadczenia usług edukacyjnych, zdrowotnych, ich prawidłowego kontraktowania oraz wyceny standardów i certyfikatów. Mieszkaniec gminy w postępujący sposób jest traktowany jako klient, do którego kierowane sa świadczenia, a coraz mniej jako podmiot samorządu lokalnego. Mówi się więc o mierzeniu zadowolenia klienta, zarządzaniu lokalnym i o doskonaleniu technik obsługi klienta ${ }^{2}$.

To charakterystyczne, że debata naukowa nad administracją świadcząca i jej teoretycznymi problemami oraz nad samorządem terytorialnym przebiegały często odrębnie. Można oczywiście twierdzić, że w gruncie rzeczy nic się nie zmieniło: samorząd terytorialny, mimo że często wycofywał się na pozycję podmiotu kontraktującego, kontrolera i nadzorcy - nadal pozostaje dysponentem zadań i nie został zwolniony z ustawowej odpowiedzialności za ich wykonywanie. Jest to jednak słaba pociecha. Zmiany sytuacji prawnej widoczne

\footnotetext{
${ }^{1}$ E. Forsthoff, Die Verwaltung als Leistungsträger, Stuttgart 1938.

${ }^{2}$ Por.: B. Sorychta-Wojsczyk, Zarzqdzanie gmina a przedsiębiorstwem - cechy wspólne i różnice, „Zeszyty Naukowe Politechniki Śląskiej. Organizacja i Zarządzanie” 15, 2003, s. 113 i n., a także: B. Kożuch, T. Markowski (red.), Z teorii i praktyki zarzqdzania publicznego, Białystok 2005.
} 
sa gołym okiem i skłaniają do postawienia pytania, które sformułował jeden z młodych wyborców przed ostatnimi wyborami do samorządu terytorialnego: Czy nie powinniśmy już raczej wybierać firm, które realizuja usługi w naszej gminie, a następnie potwierdzać ich kontrakt co cztery lata? Takie sformułowanie uderza $\mathrm{w}$ dotychczasowe zasady realizacji przez samorząd dobra wspólnego na poziomie lokalnym i regionalnym, a poczucie podmiotowości i wspólnoty zostaje zastapione poczuciem bycia lepiej lub gorzej obsługiwanymi klientami żądającymi dobrych standardów.

Pojęcie administracji świadczącej służyło zbiorczemu ujęciu poszczególnych rodzajów administracji, których wspólnym mianownikiem było świadczenie na rzecz człowieka, wyposażanie go w określone zasoby materialne, otaczanie pieczą publiczna, zapewnienie bezpieczeństwa socjalnego ze strony państwa. Wielki podział na administrację reglamentacyjną o charakterze policyjnym - skupiona na „odwracaniu niebezpieczeństwa” i administrację świadcząca opiekuńczą wobec obywatela i wspólnoty nie wykluczał obszarów swoistego miękkiego pogranicza, takich jak np. bezpieczeństwo żywności i żywienia (jest to równocześnie świadczenie administracji - także na poziomie lokalnym w zakresie bezpieczeństwa i higieny żywności) czy ochrona konsumentów ${ }^{3}$. Mimo że nie odnajdowało to bezpośredniego odzwierciedlenia w prawie administracyjnym, tendencja była jasna; bezpieczeństwo wewnętrzne i zewnętrzne o różnym charakterze pozostaje raczej w gestii administracji rządowej - samorząd ma „troszczyć się” o mieszkańca i jego potrzeby - bardziej nawet niż o prawa. Ważne wydawało się skuteczne dostarczenie świadczenia (administracja centralna), piecza miała pozostawać w gestii administracji samorządowej.

Dla skutecznej analizy tematu należy więc cofnąć się do podstawowego pojęcia administracji świadczącej i zastanowić się nad jego obecnym stosowaniem ${ }^{4}$. W literaturze znajdujemy zastanawiające wypowiedzi w tym zakresie. Stanisław Nitecki stwierdza np., że zakres zadań realizowanych przez administrację - również samorządową - rozszerza się i obejmuje nowe obszary życia codziennego ${ }^{5}$. Nie używa jednak kategorii administracji świadczącej, lecz wyróżnia dwie podstawowe funkcje administracji: policję i pieczę. Równocześnie istniejące opracowania ${ }^{6}$ wskazują na to, że administracja świadcząca wciąż

${ }^{3}$ Zob. M. Korzycka-Iwanow, Ochrona zdrowia konsumenta $w$ nowej ustawie o warunkach zdrowotnych żywności i żywienia, „Kwartalnik Prawa Publicznego” 10, 2001, nr 3, a także J. Boć, O bezpieczeństwie wewnętrznym, w: A. Chajbowicz, T. Kocowski (red.), Bezpieczeństwo wewnętrzne $w$ dziataniach terenowej administracji publicznej, Wrocław 2009, s. 19-28.

${ }^{4}$ Zob. więcej: I. Lipowicz, Istota administracji, w: Z. Niewiadomski (red.), Prawo administracyjne, Warszawa 2013.

${ }^{5}$ S. Nitecki, Infrastruktura pomocy społecznej jako dobro publiczne, w: M. Woźniak, E. Pierzchała (red.), Dobra publiczne w administracji Torun 2014, s. 119.

${ }^{6}$ I. Sierpowska, Pomoc społeczna jako administracja świadczaca. Studium administracyjnoprawne, Warszawa 2012. 
jest odnoszona do konkretnego, ważnego dla człowieka działania administracji samorządowej, ale nie zawsze analizowana w planie ogólnym.

Samorząd terytorialny ma w swej istocie wpisaną praktycznie całość klasycznych kompetencji i zadań administracji świadczącej, nawet jeżeli w niektórych kwestiach (np. pomocy społecznej) mamy do czynienia z podziałem kompetencji w tym zakresie między różne szczeble samorządu i administracji rządowej. Zwróćmy uwagę na to, jak opisywana jest np. kompetencja świadczenia pomocy mieszkaniowej przez samorzą ${ }^{7}$. Wojciech Federczyk wskazuje ${ }^{8}$, że formy pomocy mieszkaniowej pojawiły się „wraz z rozszerzaniem się zakresu opiekuńczej działalności państwa”. Oczywiście formy tej pomocy sa zróżnicowane; nikt jednak nie kwestionuje w polskiej literaturze tego, że mieszkaniowy zasób komunalny ma umożliwiać realizację zadań gmin w tym zakresie ${ }^{9}$. Można dostrzec tu interesująca ewolucję. W latach dziewięćdziesiątych przyjmowano, że ze względu na umowny charakter stosunku najmu gospodarowanie zasobem mieszkaniowym ogranicza się do czynności prawnych. Oznaczało to, że okoliczności związane z zawarciem najmu lokalu komunalnego - mające często charakter ważki społecznie, dotyczacy np. wykluczenia społecznego ${ }^{10}$ czy ubóstwa, a więc kwestii będacych z zasady w zakresie działania sądów administracyjnych - podlegały kognicji sądów powszechnych. Przyjęcie poglądu, że najem lokali komunalnych stanowić miałby tylko cywilnoprawne gospodarowanie zasobem, oznaczało podważenie nie tylko przynależności tego zasobu do kategorii rzeczy publicznych, lecz także „przesunięcie granicy” administracji świadczacej. Na wniosek Rzecznika Praw Obywatelskich uchwała siedmiu sędziów Sądu Najwyższego w $1997 \mathrm{r} .{ }^{11}$ spowodowała zasadniczą zmianę w podejściu do kwalifikacji umowy najmu. Zdaniem Sąu Najwyższego nie jest to czynność z zakresu administracji publicznej, w związku bowiem z dysponowaniem lokalami poprzez umowy najmu, a więc czynności cywilnoprawne, wybór osoby do zawarcia umowy najmu lokalu mieszkalnego z mieszkaniowego zasobu gminy nie jest aktem lub czynnością z zakresu administracji publicznej, który podlega kontroli Naczelnego Sądu Administracyjnego. Zasadniczo inne stanowisko przyjął Naczelny Sąd Administracyjny, który w uchwale siedmiu sędziów stwierdził, że: „realizacja zadania polega na dokonaniu oceny, czy określona osoba, będąca członkiem wspólnoty samorządowej, może uzyskać

\footnotetext{
${ }^{7}$ Zob. szerzej: M. Pyziak-Szafnicka, Uwagi na temat cywilnoprawnego i konstytucyjnego ujęcia własności jednostek samorzqdu terytorialnego, „Samorząd Terytorialny” 9, 1999, nr 10.

${ }^{8}$ W. Federczyk, Problemy wykorzystania gminnych zasobów mieszkaniowych, w: M. Woźniak, E. Pierzchała (red.), op. cit., s. 347 i n.

${ }^{9}$ W. Federczyk, Wybrane problemy ochrony praw lokatora i gospodarki mieszkaniowej, „Samorząd Terytorialny" $18,2008, \mathrm{nr} 4$.

${ }_{10}$ Zob. szerzej: R. Giermakowska, Wykluczenie społeczne. Cechy konstytutywne kategorii $i$ ich empiryczne egzemplifikacje, w: A. Rączaszek, W. Koczur (red.), Polityka społeczna w życiu społeczno-gospodarczym kraju, Katowice 2007, s 141 i n.; R. Szarfenberg, Pojęcie wykluczenia społecznego, w: M. Duda, B. Gulla (red.), Przeciw wykluczeniu społecznemu, Kraków 2008, s. 11; R. Antonów, Wykluczenie społeczne jako problem polityki społecznej Unii Europejskiej, w: E. Kozerska, T. Scheffler (red.), Aksjologiczne i praktyczne aspekty integracji europejskiej, Wrocław 2008, s. 145; J. Damon, Wykluczenie, Warszawa 2012.

${ }_{11}$ Uchwała 7 sędziów Sądu Najwyższego z 5 listopada 1997 r., III ZP 37/97, OSNAPiUS 1998, nr 7 , poz. 200 .
} 
pomoc gminy w zaspokajaniu jej potrzeb mieszkaniowych w drodze zakwalifikowania jej do kręgu osób, z którymi może być zawarta umowa najmu lokalu z mieszkaniowego zasobu gminy. To działanie ma wszelkie cechy załatwiania sprawy z zakresu administracji publicznej, zarówno ze względu na przedmiot sprawy, jak i organ powołany do załatwienia takiej sprawy" ${ }^{12}$. Późno i niekonsekwentnie, ale w podobnym kierunku ustawodawca zmienił swoje podejście do mieszkań zakładowych ${ }^{13}$.

Określenie granic administracji świadczącej nie przebiegało więc jednorazowo ani tylko w jednym kierunku. W przypadku zasobu mieszkaniowego mieliśmy więc do czynienia ze swoistym odwojowaniem dla prawa administracyjnego i kategorii administracji świadczącej obszaru, który w latach dziewięćdziesiątych uznany został już za obszar podlegający regulacji prawa cywilnego. Wskazuje to dodatkowo, przy porównaniu obu uchwał, jak dotkliwie brak w katalogu prawnych form działania administracji ostatecznego uznania umowy administracyjnej ${ }^{14}$ - ważnego instrumentu funkcjonowania administracji świadczącej w innych krajach ${ }^{15}$. Kwestia gospodarowania zasobem komunalnym stanowi jednak pewien wyjątek. Ogólnie bowiem mamy do czynienia z ewolucja przebiegajaca w odwrotnym kierunku: obszary w sposób niekwestionowany „administracyjnoprawne”, takie jak opieka zdrowotna czy podstawowa oświata, stopniowo przechodzą pod rządy prawa cywilnego, w związku z postępująca prywatyzacja.. „Wychodzą” one w ten sposób z reżimu prawa administracyjnego także w zakresie kontroli i nadzoru. W zaskakujący sposób administracja publiczna - w tym samorządowa - zyskuje jednak nowe kompetencje w związku z publicyzacją obszarów przez długie wieki należących do życia prywatnego. Sytuacja, w której samorząd terytorialny, w zależności od swoich opcji politycznych i socjalnych, dofinansowuje zabiegi in vitro, szczepienia HCV dla dziewcząt, czy ogólnie - rodziny wielodzietne albo zajmuje się również przemoca wobec kobiet, która nie jest już rozpatrywana wyłącznie w aspekcie prawa karnego czy waskiego obszaru pomocy społecznej dla ofiar przemocy ${ }^{16}$, ale jako całościowy obszar ważnej polityki publicznej, ma już często miejsce. Prywatyzacja licznych i tradycyjnych obszarów pozostających w zainteresowaniu prawa publicznego i publicyzacja tego, co niegdyś było ściśle prywatne i poddane wyłącznemu działaniu prawa cywilnego ${ }^{17}$, wydaje

12 Uchwała 7 sędziów Naczelnego Sądu Administracyjnego z 21 lipca 2008 r., I OPS 4/08, ONSAiWSA 2008, nr 6, poz. 90.

${ }^{13}$ Zob. wystapienie Rzecznika Praw Obywatelskich do Prezesa Rady Ministrów w sprawie trudnej sytuacji prawnej najemców byłych mieszkań zakładowych, RPO/508492/05/IV/506.1 RZ.

14 Zob. więcej: Z. Cieślik, Umowa administracyjna w państwie prawa, Kraków 2004.

15 Zob. A. Bleckmann, Der Verwaltungsvertrag als Handlungsmittel der Europäischen Gemeinschaften, „Deutsche Verwaltungsblatt” 1981, nr 19 oraz idem, Verfassungsrechtliche Probleme des Verwaltungsvertrages, „Neue Zeitschrift für Verwaltungsrecht” 1990, nr 7.

${ }_{16}$ M. Andrzejewski, Ochrona praw dziecka w rodzinie dysfunkcyjnej. Dziecko - rodzina-państwo, Kraków 2003.

17 Zob. więcej: A. Doliwa, S. Prutis (red.), Kryzys prawa administracyjnego t. 3: Wypieranie prawa administracyjnego przez prawo cywilne, Warszawa 2012; jako pierwszy w polskiej literaturze na to zjawisko wskazywał Jan Jeżewski w publikacji Administracja pod rzqdem prawa cywilnego. Z badań porównawczych nauki prawa administracyjnego (Wrocław 1974). 
się trendem stałym, choć nie jesteśmy w stanie przewidzieć jeszcze obecnie wszystkich odległych konsekwencji tego procesu dla samorządu ${ }^{18}$.

Mówimy o dwóch obliczach administracji świadczącej: to przecież po pierwsze piecza dla dobra konkretnego człowieka, po drugie działanie na rzecz całej społeczności ${ }^{19}$. Hartmut Maurer postrzegał cel działania administracji świadczącej w zapewnieniu obywatelowi odpowiednich warunków życiowych, a także ich stopniową poprawę ${ }^{20}$. To także ogólny cel działania samorządu terytorialnego. Bardzo charakterystyczne dla samorządu jest właśnie połączenie pieczy indywidualnej ze świadczeniem na rzecz całej społeczności. Jeszcze kilka lat temu jako rzecz oczywistą ujmowano w podręcznikach to, że to administracja - także samorządowa - organizuje budowę dróg, wodociagów i kanalizacji, parków i publicznych placówek kultury ${ }^{21}$. Obecnie w literaturze więcej przeczytamy jednak o prawidłowym przeprowadzeniu zamówienia publicznego $^{22}$. Również zapewnienie pomocy społecznej, klasyczna przecież część administracji świadczącej, a także prowadzenie szkół, przedszkoli, szpitali w obliczu postępującej prywatyzacji musi być opisywane w sposób coraz bardziej zróżnicowany. To często towarzystwo oświatowe lub firma prywatna jest już właścicielem szkoły, a samorząd pozostaje „podmiotem prowadzącym” w sensie coraz bardziej oddalonym od rzeczywistej działalności pedagogicznej ${ }^{23}$.

\section{III}

Jak możemy sformułować współczesny dylemat działań samorządu terytorialnego? Jednym ze źródeł sukcesu samej instytucji, podstawą jej legitymacji i akceptacji społecznej był nie tylko akt wyborczy, ale także delegowanie na przedstawicieli społeczności lokalnej administrowania istotnymi zadaniami publicznymi w zakresie codziennych spraw mieszkańców, wykonywanie władztwa administracyjnego nad terytorium, ludźmi, a także oczekiwanie efektywnego zarządzania mieniem komunalnym ${ }^{24}$. W dążeniu do racjonaliza-

${ }^{18}$ L. Zacharko, Prywatyzacja zadań publicznych, Katowice 2010; eadem, Poglady doktryny na temat granic prywatyzacji zadań publicznych gminy, w: E. Ura (red.), Jednostka wobec dziatań administracji publicznej. Międzynarodowa Konferencja Olszanica 21-22 maja 2001, Rzeszów 2001.

${ }_{19}$ Zob. więcej: J. Boć, Obywatel wobec ingerencji współczesnej administracji, Acta Universitatis Wratislaviensis, Wrocław 1985.

${ }^{20}$ H. Maurer, Ogólne prawo administracyjne, Wrocław 2003.

${ }^{21}$ M. Karcz-Kaczmarek, Kultura jako zadanie samorzadu terytorialnego. Doświadczenia $i$ wyzwania, w: J. Sługocki (red.), Dwadzieścia lat doświadczeń samorzqdu terytorialnego w Polsce, PWSZ, Gorzów Wlkp. 2011.

${ }^{22}$ Zob. E. Knosala, Teoretyczne aspekty stosowania prawa prywatnego $w$ działaniu wspótczesnej administracji publicznej, w: M. Wierzbowski et al. (red.), Współczesne zagadnienia prawa i procedury administracyjnej. Księga jubileuszowa dedykowana Prof. zw. dr hab. Jackowi M. Langowi, Warszawa 2009.

${ }^{23}$ E. Majchrowicz-Jopek, Wybrane problemy wykonywania zadań oświatowych przez j.s.t., „Kwartalnik Kolegium Ekonomiczno-Społecznego. Studia i Prace” 2012, nr 4(12).

${ }^{24}$ B. Jaworska-Dębska, Zadania samorzqdu terytorialnego, w: M. Stahl (red.), Prawo administracyjne. Pojeccia, instytucje, zasady w teorii i orzecznictwie, Warszawa 2013. 
cji wykonywanych zadań dawno już przekroczyliśmy granice ograniczonego outsourcingu ${ }^{25}$. Prywatyzacja zadań zaczyna dotyczyć prywatyzacji całości usług edukacyjnych lub zdrowotnych ${ }^{26} \mathrm{z}$ zakresu administracji świadczącej. Akceptujemy to w skali centralnej, np. w zakresie energii czy telekomunikacji. Tam, nawet jeżeli państwo wycofuje się na pozycję regulatora i nadzorcy, zachowuje zwykle wystarczający wpływ, natomiast w przypadku samorządu takie głębokie wycofanie podważać może podstawy legitymacji demokratycznej, która w przypadku samorządu miała zawsze podwójny charakter: płynęła nie tylko z Konstytucji i ustawy, ale też z woli społeczności lokalnej. Postępujące zmiany naruszają tę równowagę.

Erozja klasycznej pozycji prawnej samorządu dotyczy też innej kwestii. Obywatele w coraz większym stopniu chca „odzyskać” dla siebie bieżący udział w (poprzednio bezpowrotnie, z wyjątkiem wyborów i referendum, delegowanym na swych przedstawicieli na okres kadencji) procesie decyzyjnym. Wykraczamy tu poza obszar lepszej informacji publicznej, skutecznego prawa do informacji publicznej o działaniu samorządu czy wreszcie konsultacji społecznych, których wyniki się respektuje. Powrót demokracji bezpośredniej po latach uwiądu ma nową formę nie tylko budżetów obywatelskich, ale także rad seniorów czy rad młodzieżowych, a także obudowywania samorządów innymi ciałami obywatelskimi. Często jednak samorząd chroni się za bariera dość formalnych konsultacji obywatelskich traktowanych tylko jako uciążliwy obowiązek. Równocześnie nieproporcjonalnie słabnie pozycja Rady na rzecz silnej pozycji organu wykonawczego. W tę próżnię wchodzą nowe gremia konsultacyjne i obywatelskie - stopniowo Rada, mimo swoich zasadniczych konstytucyjnych kompetencji, staje się faktycznie tylko jednym z wielu organów, z którymi na co dzień kooperuje wójt, burmistrz bądź prezydent. Pozwala im pomniejszyć wyjątkowość Rady.

Ten nowy krajobraz ustrojowy dotyczy również wykonywania administracji świadczącej. Kryteria dobra wspólnego, zapobieżenia dyskryminacji czy wykluczeniu społecznemu trudno przekładają się na rzeczywistość firmy rozliczanej z efektywności i wyników finansowych. Zderzenie z nowa rzeczywistością ma czasami charakter brutalny, np. odkrycie, że sprywatyzowany szpital $\mathrm{w}$ pogoni za redukcją kosztów ucieka od najbardziej skomplikowanych i niebezpiecznych zabiegów ważnych dla mieszkańców, skazując ich $\mathrm{np}$. na długotrwały transport związany $\mathrm{z}$ ryzykiem dla ich zdrowia i życia. Placówka taka może się jednak pochwalić świetnymi wynikami finansowymi oraz certyfikatem ISO 9001. Równocześnie, ponieważ np. hospicjum domowe wyrastające kiedyś z ruchu społecznego Solidarność nie może opłacić kosztów takiego uzyskania certyfikatu ISO, traci często kontrakt NFZ-etu na rzecz prywatnej firmy. Być może jest to już część szerszego procesu, polegającego na wypieraniu prawa administracyjnego przez zarza-

${ }^{25}$ Zob. G. Krawiec, Założenia koncepcji good governance wobec materialnych, proceduralnych $i$ ustrojowych zasad prawa administracyjnego, w: I. Niżnik-Dobosz (red.), Zastosowanie idei public governance w prawie administracyjnym, Warszawa 2014, s. 15 i n.

${ }^{26}$ M. Janik, Zdrowie jako dobro publiczne $w$ dobie globalizacji - kilka uwag dyskusyjnych, w: M. Woźniak, E. Pierzchała (red.), op. cit. 
dzanie administracją publiczna, gdyż właśnie w prawo administracyjne, przez dziesięciolecia doświadczeń, precyzyjnie wbudowano elementy dobra wspólnego. W przypadku zarządzania zmierzamy natomiast głównie do racjonalizacji wydatków publicznych oraz uzyskania czasem dość iluzorycznego stopnia zadowolenia ze świadczenia administracyjnego ${ }^{27}$. Oczywiście takim działaniem może się wykazywać także gmina odmawiająca budowy mieszkań socjalnych czy schronisk dla bezdomnych.

\section{IV}

Administracja świadcząca załamuje się na naszych oczach niejako pod własnym ciężarem: z jednej strony państwa uciekają od nadmiernych według ich ministerstw finansów obciążeń socjalnych, z drugiej - świetne niegdyś zabezpieczenie niektórych pracowników administracji świadczącej, np. nauczycieli w przypadku Karty nauczyciela czy maszynistów bądź pracowników wybranych służb miejskich, staje się bariera zmian. Nie są oni przecież skłonni do rezygnacji ze swojej - z trudem zdobytej - pozycji socjalnej. W warunkach kryzysu staje się to paradoksalnie powodem do wręcz całkowitego porzucenia bezpośredniej realizacji zadań publicznych i wycofywania się z nich przeciążonych samorządów.

Administracja stale już negocjuje, obiecuje ulgi i kontrakty socjalne; działa w sposób coraz bardziej pośredni. To miękkie działanie sprawia jednak, że łatwo pogorszyć sytuację prawną adresata świadczenia, uciekając pierwotnie od decyzji administracyjnej ${ }^{28}$. Odbiorcy świadczeń, którzy dawniej mogli się domagać ich realizacji ze strony lokalnej administracji świadczacej, wobec sprywatyzowanych podmiotów, poszukuja ochrony już tylko jako konsumenci, a uzyskanie przez obywatela szybkiej reakcji administracji, która teoretycznie przecież zachowała odpowiedzialność za bezpieczeństwo socjalne czy bezpieczeństwo energetyczne, jest dużo trudniejsze niż niegdyś. Zapominamy, że część zaufania i prestiżu samorządu - wciąż u nas wysokiego - brała się przecież właśnie z poczucia bezpośredniej przydatności w społeczności lokalnej silnej więzi społecznej. Organy gminy czy powiatu nie były jakimś dalekim i abstrakcyjnym nadzorcą czy kontrolerem, pozostawały bezpośrednim stałym organizatorem życia społecznego. Można oczywiście twierdziće ${ }^{29}$, że zarówno prywatyzacja, jak i kontraktowanie usług publicznych są elementem triumfu dwustronności nad jednostronnością klasycznego prawa administracyjnego, partnerstwa obywatelskiego.

${ }^{27}$ K. Wilk-Widuch, Wykorzystanie faktu wdrażania systemu zarzadzania przez jakość (normy ISO z serii 9000) jako instrumentu budowania pozytywnego wizerunku administracji publicznej, w: M. Tabernacka, A. Szedok-Bratuń (red.), Public relations. Wizerunek i komunikacja, Warszawa 2012 .

${ }^{28}$ Zob. szerzej: M. Jaśkowska, Wpływ zmian $w$ k.p.a. na sferę praw $i$ wolności jednostki, w: T. Górzyńska, G. Sibiga, M. Błachucki (red.), Analiza i ocena zmian Kodeksu postepowania administracyjnego $w$ latach 2010-2011, Warszawa 2012, s. 11 i n.

${ }^{29}$ Z. Bukowski, Zrównoważony rozwój w systemie prawa, Warszawa 2009. 
W świadomości społecznej samorząd terytorialny jest nieodłącznie związany z różnymi świadczeniami na rzecz obywateli. Aktywne wpływanie na sferę socjalną i życie gospodarcze (i to nie w sposób punktowy, ale ciagły) stworzyło rzeczywistość, w której funkcjonuje polski samorząd terytorialny - niekwestionowany przez żadną większą partię polityczna. Trudno nam wyobrazić sobie czasy apogeum państwa - nocnego stróża, w którym „pozytywne”, organizujące działanie państwa było uważane wręcz za szkodliwe. Jak wskazuje Zygmunt Niewiadomski, samorzą „staje się obok instytucji publicznej bezpośrednio powołanej do świadczenia usług, realizatorem idei państwa dobrobytu". Długo trwało stałe rozszerzanie zakresu działania samorząu terytorialnego po II wojnie światowej, z tego procesu byliśmy z przyczyn historycznych wyłączeni. Autor dalej wskazuje, że zasadę ograniczonej pojemności kompetencyjnej państwo ograniczało do administracji rządowej, samorządowi do końca XX w. przekazywano je praktycznie bez ograniczeń. Istnieje przecież także określona pojemność kompetencyjna samorządu terytorialnego. Doświadcza tego polski samorząd, który według kryterium lokalności lub regionalności jest odpowiedzialny jednocześnie za planowanie przestrzenne, utrzymywanie infrastruktury, drogi lokalne, usuwanie ścieków czy utrzymywanie urządzeń sportowych.

Autor słusznie wskazuje, że zmianie podlega ogólna formuła zadaniowa współczesnego samorządu terytorialnego, i stawia tezę, iż samorząd terytorialny „podejmuje obecnie wszystkie zadania, które bezpośrednio, a nawet pośrednio, kształtują sytuację obywatela, przy czym następuje wyraźne przesunięcie akcentu z zadań o charakterze policyjno-porządkowym na zadania polegające na rozbudowie i utrzymaniu infrastruktury technicznej i społecznej”30.

Jak wskazuje Małgorzata Stahl, określanie celów i zadań publicznych jest zmienne $\mathrm{w}$ czasie $\mathrm{i} \mathrm{w}$ przestrzeni, a $\mathrm{w}$ obliczu przemian administracji publicznej utraciła - jak wskazuje autorka - w pewnym zakresie znaczenie teza, że interes społeczny jako cecha działania odnosi się do całokształtu działania administracji. Stahl podkreśla, że za zasadnicze cele władzy wykonawczej uważa się m.in. zapewnienie stabilizacji, gospodarczego i społecznego dobrobytu dla wszystkich obywateli. To także tradycyjne przesłanki wyodrębnienia administracji świadczącej. Wydaje się więc, że erozja administracji świadczącej nie następuje na poziomie „wielkich” celów działania administracji - i to w sposób wspólny dla literatury prawnej i politologicznej - ale jak wskazuje Teresa Rabska, to zmiana ról pełnionych przez państwo prowadzi do zmiany jego celów i zadań oraz do zmiany sposobu ich realizacji, a to z kolei rozsadza ramy strukturalne administracji ${ }^{31}$. Wydaje się więc, że proces, który następuje w samorządzie terytorialnym, po 25 latach galopujaccej prywatyzacji to właśnie owo „rozsadzanie ram strukturalnych” w administracji lokalnej ${ }^{32}$. Jakie konsekwencje może mieć takie rozsadzanie ram administracji samorządowej?

${ }^{30}$ Z. Niewiadomski, w: System prawa administracyjnego, t. 6: Podmioty administrujace, red. R. Hauser, Z. Niewiadomski, A. Wróbel, Warszawa 2011, s. 146.

${ }^{31}$ T. Rabska, Przywracanie ciagtości pojęć prawnych, w: Państwo prawa. Administracja. Sadownictwo. Prace dedykowane prof. dr. hab. Januszowi Łętowskiemu, Warszawa 1999, s. 214 i n.

${ }^{32}$ M. Stahl, w: System..., t. 6, s. 95 i n. 
Czy rzeczywiście nastapiła już zmiana roli państwa w tym zakresie? Wymaga to dalszych badań, ale także krytycznej refleksji w zakresie nauki prawa administracyjnego.

Jakie jednak rysuje się wyjście z tej sytuacji? Być może powinniśmy posuwać się już krok dalej i poddawać refleksji swoiste finalitè zakresu prywatyzacji administracji świadczącej w samorządzie terytorialnym dla ochrony pewnego rdzenia działań administracji, które pozwola zachować sens wykonywania bezpośredniego władztwa publicznego, realizacji dobra wspólnego poprzez administrowanie, a nie tylko działać za pośrednictwem wynajętych firm i innych podmiotów. Brak przy tym rozróżnienia w zlecaniu administracji publicznej podmiotom komercyjnym i tym społecznym, które nie działają dla maksymalizacji zysków. Nie oznacza to generalnego odrzucenia prywatyzacji, jeżeli jednak w literaturze ${ }^{33}$ znajdujemy stwierdzenie, że „nie można udzielić jednoznacznej odpowiedzi, jaki katalog zadań publicznych może być przekazany podmiotom niepublicznym, gdyż jest to uzależnione od konkretnych warunków, w jakich działa samorząd terytorialny", to choć jest to odpowiedź w obecnym stanie prawnym zasadna, jest ona niepokojaca. Następuje bowiem swoista atomizacja redefiniowania dobra wspólnego i ustalanie zakresu odpowiedzialności administracji w sposób „od przypadku do przypadku".

Wydaje się, że powinniśmy pójść krok dalej. Poddajemy się pewnej narracji narzuconej przez teorie zarządzania, mówimy bowiem już powszechnie o produktach, klientach ${ }^{34}$. Z bezpośredniego zaspokajania potrzeb społecznych, jednostki samorządu terytorialnego przeszły na aktywna politykę inspirowania i sterowania rozwojem gospodarczym. Traktuje się rolę samorządu z pozycji jednego z wielu podmiotów gospodarczych działających na rynku, niczym się nieróżniących w zabieganiu o „klienta” ${ }^{35}$.

Samorząd terytorialny po 25 latach to wciąż niezwykły historyczny eksperyment, ale i wielki sukces ${ }^{36}$. To stan głębokiej reformy i dużego dynamizmu jednej części aparatu państwowego i stagnacji, swoistego zastygnięcia w dawnych formach drugiej części aparatu administracyjnego. Ta pierwsza część to samorząd - druga to administracja centralna. Czy mamy dzisiaj twarde dowody na wyższą efektywność działania i lepsze administrowanie ze strony samorządu terytorialnego? Wydaje się, że takim roboczym miernikiem dobrej administracji może być procent decyzji uchylanych rok po roku przez sądy administracyjne. Obecnie przeciętnie jest to średnio $22 \%$ decyzji i innych rozstrzygnięć. Tymczasem w odniesieniu do administracji centralnej w $2014 \mathrm{r}$. było to ponad 35\%, a w przypadku niektórych resortów (Ministerstwo Finan-

${ }^{33}$ L. Zacharko, Refleksja nad kategoria dobra publicznego, w: M. Woźniak, E. Pierzchała (red.), op. cit.

${ }^{34}$ Zob. szerzej: I. Lipowicz, Dylematy zmiany siatki pojęciowej $w$ nauce prawa administracyjnego, w: J. Zimmermann (red.), Koncepcja systemu prawa administracyjnego. Zjazd Katedr Prawa Administracyjnego i Postepowania Administracyjnego, Zakopane, 24-27 września 2006 r., Warszawa 2007, s. 26.

35 R. Hauser, Z. Niewiadomski, A. Wróbel, System..., t. 6, s. 152.

36 B. Gąciarz, Instytucjonalizacja samorzadności. Aktorzy i efekty, Warszawa 2004. 
sów) nawet $59 \%$, i to mimo tego, że przecież to administracja centralna jest lepiej niż lokalna wyposażona w zasoby i usługi prawnicze wysokiej jakości ${ }^{37}$. Brak modernizacji administracji centralnej wywołuje przeciążenie samorządu i czasem dramatyczne próby odciążenia np. przez prywatyzację szkół czy szpitali $^{38}$.

Interesującym wątkiem pozostaje zorganizowanie systemu administracji publicznej według zasady pomocniczości. W literaturze funkcjonuje już pojęcie pomocniczej administracji publicznej ${ }^{39}$, w której jej częścią jest administracja sformowana przez prywatyzację realizacji zadań pierwotnie powierzonych jej przez ustawodawcę ${ }^{40}$. Oznacza to przyjęcie możliwości stworzenia takiego systemu podmiotów administrujących, w którym zadania i kompetencje przypisywane sa przede wszystkim podmiotom społecznym. Tak postrzega realizację zasady pomocniczości również Stanisław Fundowicz ${ }^{41}$, stwierdzając, że zasada pomocniczości wymaga także uznania aktywności innych podmiotów niż państwo w sferze wykonywania zadań publicznych. Wydaje się, że mamy tu do czynienia z pewnym problemem określenia charakteru prawnego podmiotów. Należy zgodzić się z autorem, że jeśli podmioty społeczne: stowarzyszenia, fundacje lub zrzeszenia moga zrealizować zadania publiczne, to państwo zgodnie z zasada pomocniczości nie powinno ich w tym wyręczać. Do podobnego wniosku dochodzą współcześnie - wychodząc z zupełnie innej oceny aksjologicznej - Brytyjczycy w swojej koncepcji Big Society ${ }^{42}$. Brak jednak rozróżnienia podmiotów administrujących: podmiotów rzeczywiście społecznych i firm dążących do maksymalizacji zysków. W dalszym ciągu dostrzegam problem w kontraktowym przekazywaniu kompetencji - powinna tu w moim przekonaniu występować podstawa ustawowa. Jeśli władztwo publiczne powierzamy firmie, a łączy się ono także z prawem stosowania mniej lub bardziej ukrytego przymusu, to trudno usprawiedliwić taka „,wolną” decentralizację. Trudno bowiem mówić o samodzielności prawnej i determinacji w realizacji dobra wspólnego na podstawie ustawy; cele firmy są po prostu inne. Należałoby więc mocniej w prawie administracyjnym rozróżniać podmioty sprawujące pomocnicza

37 Zob. Informacja o działalności sadów administracyjnych w 2014 roku, Warszawa 2015.

${ }^{38}$ E. Popławska, Wpływ zasady subsydiarności na przemiany ustrojowe w Polsce, w: D. Milczarek (red.), Subsydiarność, Warszawa 1996.

39 T. Bąkowski, Administracyjnoprawna sytuacja jednostki w świetle zasady pomocniczości, Warszawa 2007.

${ }^{40}$ Ibidem, s. 201 i n.

41 S. Fundowicz, Dynamiczne rozumienie zadania publicznego, w: J. Supernat (red.), Między tradycja a przyszłościa $w$ nauce prawa administracyjnego. Księga jubileuszowa dedykowana Profesorowi Janowi Bociowi, Wrocław 2009, s. 165.

${ }^{42}$ M. Scott, Reflections on 'The Big Society', „Community Development Journal” 46(1), 2011, s. $132-137$. 
administrację publiczna, a całkowitą prywatyzację zadań ograniczyć raczej do podmiotów komercyjnych ${ }^{43}$.

Czy alternatywą byłoby uspołecznienie zadań w odróżnieniu od prywatyzacji? Prywatyzacja dotyczyłaby w pełni podmiotu prywatnego w sensie prawa gospodarczego, uspołecznienie (w odnowionym znaczeniu) - podmiotu, który nie dąży do maksymalizacji zysków ${ }^{44}$, lecz przeznacza je na cele społeczne i rozwój własny. Należy zgodzić się z tym, że administracja zawsze działa w warunkach niestabilności. Zlecanie zadań podmiotom niepublicznym i prywatyzacja (Stahl odróżnia te dwie formy ${ }^{45}$ ) niewątpliwie zmienia model administracji w kierunku jej pól realizacji. Koncepcja państwa sieciowego miała stanowić teoretyczna konsekwencję tych przemian. Zarządzanie wielopoziomowe, czyli multilevel governance pozostaje jednak wciąż bardziej hasłem niż dopracowaną teorią ${ }^{46}$. Łatwo stwierdzić, że typowa dla tego państwa struktura sieciowa to organizacja w której „koordynację przez hierarchię zastępują stosunki poziome [...], a model państwa opiera się na wieloszczeblowym partnerstwie podmiotów państwowych, samorządowych, niepublicznych z przewaga więzi poziomych" ${ }^{47}$. Należy jednak pamiętać równocześnie o tym, że przewaga więzi poziomych i koordynacji obniża sprawność i szybkość działania administracji, rozmywa granice kompetencji i utrudnia zdefiniowanie odpowiedzialności za odpowiednie dysfunkcje. Oczywiście, sieć podmiotów powinna współdziałać w dochodzeniu do optymalnych rozstrzygnięć w sprawach publicznych, działając innowacyjnie i szybko przystosowując się do zmian rynkowych. Jednak wielość podmiotów i poziomów zarządzania zdecydowanie to utrudnia, a nieformalność powiązań, wygodna dla samorządów czy stowarzyszeń, może utrudniać człowiekowi oczekującemu konkretnych świadczeń od administracji odnalezienie odpowiedzialnego podmiotu. Cierpi także kategoria dystansu, stały splot samorządu i organizacji pozarządowych wykonujaccych administrację publiczną w realizacji idei governance niweluje sytuacje jasne: np. klarowne kompetencje podmiotu i wykonawcy realizujacych kontrakt - utrudniajacc pociagnięcie do odpowiedzialności za wadliwe administrowanie ${ }^{48}$. Kiedy czytamy, że następuje swoista deregulacja w postaci powierzania zadań publicznych podmiotom niepublicznym „bez pomniejszania odpowiedzialności państwa za ich właściwą realizację", widzimy, że klasyczny związek między kompetencją a odpowiedzialnością związaną ze sprawowaniem władzy ulega rozerwaniu ze szkodą dla przejrzystości administrowania i poszanowania pozycji prawnej podmiotu administrowanego ${ }^{49}$. Jerzy Supernat słusznie omawia tę nową rzeczywistość, gdyż tak jest właśnie projektowana ${ }^{50}$. Może być nawet rzeczywista

${ }^{43}$ D. Dąbek, Samodzielność ustrojowa samorzqdu terytorialnego - idea a rzeczywistość, w: B. M. Ćwiertniak (red.), Prawne problemy samorzadu terytorialnego, Warszawa 2013, s. 65 i n.

${ }_{44}$ M. Stahl, w: System..., t. 6, s. 92.

45 Ibidem.

${ }^{46}$ A. Chrisidu-Budnik, Organizacja uczaca się, w: eadem et al. (red.), Nauka organizacji i zarzadzania, Wrocław 2009, s. 485-496.

47 Eadem, Administracja publiczna w strukturze sieciowej, w: J. Supernat (red.), op. cit., s. 70.

${ }_{48}$ Zob. więcej: J. Blicharz, Udziat polskich organizacji pozarzqdowych w wykonywaniu zadań administracji publicznej, Wrocław 2005.

${ }^{49}$ H. Izdebski, J. Supernat, Fundamenty współczesnych państw, Warszawa 2007, s. 57 i n.

50 J. Supernat, Administrowanie przez sieć, w: A. M. Sosnowski (red.), Administracja publiczna. Obywatel, społeczeństwo, państwo, Wrocław 2006. 
alternatywą dla europejskiej centralizacji, z nadmierna rola Komisji Europejskiej, ale trzeba zgodzić się z konstatacją Małgorzaty Stahl i Adama Błasia, że niektóre z przyjmowanych, szczegółowych założeń są w Polsce „trudne do pogodzenia z założenia państwa prawa" ${ }^{1}$. Błaś podkreśla także, że sytuacja prawna jednostki przestaje być bezwzględnie stabilna, a zadania publiczne przekształcają się w bezpłatne usługi publiczne. Stahl zaś słusznie zauważa, że towarzyszy temu niebezpieczeństwo instrumentalizacji prawa administracyjnego dla doraźnych celów politycznych.

Alternatywą koncepcji państwa sieciowego - multilevel governance i odejścia od koncepcji praw podmiotowych stała się w Europie koncepcja nowego prawa administracyjnego Eberharda Schmidta-Assmana, Wolfganga Hoffmana-Riema i współpracowników. Koncepcja ta radzi sobie w inny sposób z kryzysem administracji i prawa administracyjnego, czyniac to bez rezygnacji z podstawowej siatki pojęciowej nauki prawa administracyjnego, a proponując równie głęboką modernizację pojęć i form działania ${ }^{52}$.

Uznawanym obecnie za klasyczny obszarem administracji świadczącej wbrew odmiennym historycznym początkom - jest świadczenie pomocy społecznej. Poprzez system pomocy społecznej, jak podkreśla Iwona Sierpowska ${ }^{53}$, państwo powinno zapewnić godne życie osobom będącym w trudnych sytuacjach życiowych czy spychanym na margines społeczny. Świadczenie z zakresu pomocy społecznej skoncentrowane jest wokół pojęcia niezbędnych potrzeb bytowych. Wokół tego pojęcia narosło zarówno interesujące orzecznictwo ${ }^{54}$, różnicujące i ukazujące ewolucje tego, co jest obecnie niezbędną potrzebą bytowa, jak i obfita literatura ${ }^{55}$.

W literaturze wskazano, że zmiana oceny niezbędnych potrzeb jest związana nie tylko z podnoszeniem standardu życia, czy przekraczaniem granic minimum biologicznego, ale że pomoc społeczna ewoluuje również w kierun-

${ }^{51}$ A. Błaś, Wspótczesne problemy prawa administracyjnego i nauki administracji, w: J. Supernat (red.), op. cit.

${ }^{52}$ Zob. E. Schmidt-Aßmann, Ogólne prawo administracyjne jako idea porzqdku, Warszawa 2011.

${ }^{53}$ I. Sierpowska, op. cit., s. 178

${ }^{54}$ Zob. wyrok NSA z 19 kwietnia 2000 r., I SA 2129/99: wyrok NSA z 21 grudnia 1999 r., I SA 1450/99: wyrok WSA we Wrocławiu z 12 marca 2008 r., IV SA/Wr 638/07; wyrok NSA z 18 lutego 1998 r., I SA 1174/97; wyrok WSA w Warszawie z 8 marca 2007 r., I SA/Wa 153/07; wyrok WSA w Poznaniu z 28 maja 2008 r., IV SA/Po 20/08; wyrok WSA w Białymstoku z 26 czerwca 2008 r., II SA/Ke 655/07.

${ }^{55}$ I. Sierpowska wskazuje, że obecnie za niezbędną potrzebę bytową nie uznaje się co prawda ani wynajęcia firmy ochroniarskiej, ani potrzeb zwierząt domowych, ani też podatku od nieruchomości, jednakże uznaje za taką potrzebę już np. pokrycie kosztów leczenia w niepublicznym zakładzie opieki zdrowotnej lub pomoc finansową na pokrycie kosztów dojazdu na rozprawę do sądu. 
ku takiego zaspokojenia potrzeb jednostki, aby jej sytuacja nie odróżniała się w sposób rażący od sytuacji innych członków społeczeństwa ${ }^{56}$.

W tym sztandarowym przykładzie współczesnej administracji świadczącej zmienia się nie tylko pojęcie niezbędnych potrzeb bytowych, ale i rodzaj świadczeń, które nie mają już tylko spowodować przezwyciężenia trudnej sytuacji, zaspokojenia konkretnej potrzeby, ale stawiany jest im cel długofalowej zmiany sytuacji życiowej odbiorcy świadczenia. Z prostej konstrukcji udzielanej przez gminę pomocy w zapewnieniu schronienia, niezbędnego pożywienia czy pochówku wyrósł skomplikowany gmach złożonej polityki społecznej, administrowanej przez gminę, a skoro zgodnie z tezą Ernesta Knosali pomoc społeczna ma zmierzać do zmniejszenia rozpiętości położenia socjalnego członków społeczeństwa, a więc swoistej korekty wskaźnika Giniego ${ }^{57}$, to możemy postawić pytanie: W jakim zakresie samorząd terytorialny i gmina uczestniczą w budowie tego złożonego gmachu? Prawo administracji świadczącej jest wzbogacane wciąż o nowe subsystemy regulacji prawa pomocy społecznej, której realizacja spada w większości na samorząd terytorialny, gdzie doszły w ostatnich latach m.in. rozszerzone wspieranie macierzyństwa i wielodzietności czy przeciwdziałanie przemocy w rodzinie. Te ostatnie kwestie z trudnością byłyby niegdyś kojarzone $\mathrm{z}$ administracja świadcząca, dziśs są uważane za niemal naturalne świadczenia samorządu, podejmowane często z własnej inicjatywy.

Legitymizacji administracji świadczącej należy poszukiwać w społecznej zasadzie gospodarki rynkowej, a także zasadach sprawiedliwości społecznej, solidarności i równości ${ }^{58}$. Wspomaganie osób ekonomicznie i życiowo słabszych, wyrównywanie szans może być wyprowadzone z tych zasad, ale stanowi także konsekwencje bycia częścią wspólnoty. Powszechnie przywołuje się także w tym kontekście zasadę subsydiarności. Warto postawić pytanie, czy rozwój prawodawstwa oraz aparatu administracji świadczacej szanuje tę zasadę wobec samorządu terytorialnego. Czy podmioty „niższego rzędu", w tym przypadku gmina i powiat, rzeczywiście podlegaja ingerencji w swoje działanie z zakresu polityki społecznej w sposób incydentalny, uzasadniony nadzwyczajnymi okolicznościami, jak tego chce Tomasz Bakowski ${ }^{59}$, czy też scentralizowana jednolita regulacja wbrew tej zasadzie nie pozwala rozwinąć samorządowi terytorialnemu wszystkich możliwości tkwiących w administracji świadczącej? Przykładem takiej ingerencji jest regulacja, w której - w zakresie pomocy społecznej - wójt jest zobligowany do przekazania kompetencji na rzecz kierownika ośrodka pomocy społecznej lub osób przez niego wskazanych ${ }^{60}$. W doktrynie jest to oceniane jako wyją-

56 E. Knosala, Zadania wspótczesnej administracji publicznej, w: M. Baron-Wiaterek (red.), Ustrojowo-prawne instrumenty polityki społecznej, Gliwice 2005, s. 38.

57 Wskaźnik Giniego, nazywany również wskaźnikiem nierówności społecznej, stosowany jest często w ekonometrii do liczbowego wyrażania nierównomiernego rozkładania dóbr. Im wyższy wskaźnik Giniego, tym nierówności w dochodach na danym obszarze są większe.

${ }^{58}$ I. Sierpowska, op. cit., s. 179.

59 T. Bakowski, op. cit.

60 Art. 110 ust. 8 ustawy z 12 marca 2004 r. o pomocy społecznej, Dz. U. 2004, Nr 64, poz. 593 ze $\mathrm{zm}$. 
tek od swobody działania gminy, wyrażony w ówczesnym artykule 39 ust. 1 ustawy o pomocy społecznej. Rola jednoosobowych organów wykonawczych jest o tyle istotna, że to im przepisy przyznaja kompetencje do wydawania decyzji administracyjnych, a te sa podstawą przyznania lub odmowy udzielenia świadczenia z pomocy społecznej. Tym samym wójt jest jedynie nominalnie upoważniony do prowadzenia orzecznictwa administracyjnego, w rzeczywistości nie jest władny do wydawania rozstrzygnięć administracyjnych w indywidualnych sprawach z zakresu pomocy społecznej ${ }^{61}$.

W gminie spotykają się oba oblicza administracji świadczącej. Świadczenia dla zbiorowości, np. korzystających z wodociagu gminnego, drogi czy domu kultury, a z drugiej strony uzasadnione dobrem wspólnym różne rodzaje pomocy lub wsparcia świadczonego jednostce. Jak wskazuje Sierpowska: „W administracji świadczącej głównym wykonawcą zadań są zakłady publiczne i przedsiębiorstwa, jednak żadna sfera administracji nie istnieje bez jej organów. W pomocy społecznej podmiotami publicznymi zajmującymi się administracją świadcząca są organy administracji publicznej z aparatem pomocniczym i zakłady administracyjne. Nie ma natomiast przedsiębiorstw użyteczności publicznej występujących w innych sferach administracji świadczącej [...]”. Zadania pomocy społecznej nie stanowią tylko i wyłącznie części funkcji świadczącej, przynależą one bowiem również do innych funkcji administracji.

Interesująca jest również ewolucja strukturalna: oprócz tradycyjnych ośrodków pomocy społecznej w gminach jako podstawowe, samorządowe jednostki organizacyjne pomocy społecznej na szczeblu powiatu ukształtowały się powiatowe centra pomocy rodzinie. Podstawy prawne ich działania, w tym zadania, regulują stosunkowo nowe ustawy z roku 1997 i z 2011 ${ }^{62}$. Jak wskazano w literaturze, realizują one model instytucjonalny pomocy społecznej, w którym głównym kryterium udzielenia pomocy staje się potrzeba, a nie wysokość osiaganych dochodów. Usługi wspomagające rodzinę we wszystkich jej funkcjach oraz w procesie odzyskiwania samodzielności stanowią zasadniczy przełom w dotychczasowym podejściu do administracji świadczącej. Są również elementem dalszej publicyzacji części sfery prywatnej życia ludzkiego, w która - z upoważnienia ustawodawcy - administracja ingeruje aktywnie. Nie jesteśmy jeszcze jednak w stanie dostrzec odległych konsekwencji takiej zmiany, być może zapowiada ona przyszłą reorganizacją świadczeń administracyjnych według zbiorczo określonych potrzeb danego rodzaju. Wymaga to jednak dalszych badań.

${ }^{61}$ Zob. wyrok NSA z 20 grudnia 2007 r., I OSK 262/07 oraz M. Węgrzyn-Skarbek, Organizacja pomocy społecznej $w$ gminach, „Administracja. Teoria, Dydaktyka, Praktyka” 2007, nr 3, s. 217-218.

${ }^{62} \mathrm{O}$ rehabilitacji zawodowej i społecznej oraz zatrudnianiu osób niepełnosprawnych; o wspieraniu rodziny i systemie pieczy zastępczej. 


\section{VII}

Wydaje się, że biegnące często odrębnie badania i debata nad administracja świadcząca oraz samorządem terytorialnym, a także prywatyzacją zadań publicznych wymagaja ponownego scalenia, a także silniejszego ponownego odniesienia do deklarowanych norm i wartości demokratycznego państwa prawnego. Często niekonsekwentna, dynamiczna zmiana regulacji dokonywana pod presją zaspokojenia bieżących potrzeb (np. oddłużenia szpitali czy konieczności zapewnienia trwałej wypłaty świadczeń) naruszyła częściowo spójność systemową. Refleksji, w moim przekonaniu, wymaga przede wszystkim możliwość określenia granic - w świetle obowiązującej Konstytucji i zasad prowadzenia polityki publicznej - docelowych granic prywatyzacji oraz optymalnego zakresu świadczeń zapewnianego obywatelom głównie przez gminę i powiat. Nie można ignorować, wzbogaconych w ostatnich latach przez literaturę i orzecznictwo, kryteriów dobra wspólnego ani zapobiegania wykluczeniu społecznemu. Dorobek w tym zakresie nie został jednak jeszcze wykorzystany $\mathrm{w}$ istniejącym ustawodawstwie. Modernizacja administracji, np. przy wykorzystaniu koncepcji tzw. nowego prawa administracyjnego, jest w pełni możliwa z zachowaniem szeregu wartości i instytucji klasycznego prawa administracyjnego ${ }^{63}$.

Po dziesięcioleciach traktowania w Europie opiekuńczej funkcji państwa jak swoistego dogmatu, co do którego można było zmieniać formy realizacji, a nie istotna treść, nie możemy wykluczyć zwłaszcza w obliczu eksplozji kosztów socjalnych starzejącej się Europy gwałtownej reakcji, swoistej próby ucieczki z powrotem w kierunku państwa - nocnego stróża, w którym nawet cierpliwe, pozytywne, organizatorskie działanie administracji uważano by często za zbędne. Istnieją już ruchy polityczne proponujące takie rozwiązania. Odpowiednia mądra organizacja administracji świadczącej przez samorząd terytorialny - przy wykorzystaniu potencjału organizacji pozarządowych jako administracji pomocniczej w ostatecznym wprowadzeniu umowy administracyjnej i utrwaleniu nowego znaczenia uspołecznienia administracji jako powierzenia podmiotom społecznym, a nie PRL-owskiej administracji - może pomóc odwrócić to zagrożenie ${ }^{64}$.

dr hab. Irena Lipowicz

Profesor Uniwersytetu Kardynała Stefana Wyszyńskiego w Warszawie,

Rzecznik Praw Obywatelskich RP w latach 2010-2015

i.lipowicz@uksw.edu.pl

${ }^{63}$ J. Jagielski, M. Wierzbowski, A. Wiktorowska, Nietypowe podmioty administrujace - kilka refleksji na tle organizacyjnych form wykonywania zadań publicznych, w: Podmioty administracji publicznej i prawne formy ich działania. Studia i materiały z Konferencji Naukowej Poświęconej Jubileuszowi 80-tych urodzin Profesora Eugeniusza Ochendowskiego, Toruń 2005.

${ }^{6}$ A. Barczewska-Dziobek, Podmioty niepubliczne $w$ sferze wykonywania zadań administracji lokalnej, w: J. Parchomiuk, B. Ulijasz, E. Kruk (red.), Dziesięć lat reformy ustrojowej administracji publicznej w Polsce, Warszawa 2009, s. 647. 


\section{SELF-GOVERNMENT AS AN ORGAN OF WELFARE ADMINISTRATION}

\section{Sum mary}

The status of self-government as an organ of welfare administration has never been questioned in the doctrine. This paper presents the changes that have occurred recently, and which result from the privatisation of public functions as well as a certain publicisation of spheres which for years were considered private. It is therefore recommended that research into the functions of administration and self-government bodies as organs of welfare administration as well as studies of the privatisation of public functions be re-combined so that they focus more strongly on the declared norms and values of a democratic state of law. Currently, inconsistent and dynamic changes in regulations are frequently introduced under pressure as a stop-gap to address current needs. What is really needed is determination, in accordance with the Constitution and the principles of public policy, of the targeted or ultimate extent of privatisation and the optimal scope of services available to citizens in their respective communes and municipalities (gmina), and districts (powiat). 